\title{
A Simple Prediction Model for PCC Voltage Variation Due to Active Power Fluctuation for a Grid Connected Wind Turbine
}

\author{
Sang-Jin Kim and Se-Jin Seong \\ Junma Engineering Co., Ltd. Dept. of Electrical Engineering, \\ Chungnam National University \\ Korea
}

\section{Introduction}

A great deal of attention is focused on the source of new renewable energy under the present circumstance that serious problems occur all over the industry and the economy due to the high cost of energy according to the high price of oil. For these reasons, wind energy has been installed all over the world and is the fastest growing energy source in the world. In cases of micro grid areas and islands that are isolated from the main power supply and are provided by electric power through diesel engines, the $\mathrm{COE}(\mathrm{Cost}$ of Energy) is much higher due to shipping expenses of materials for the generation of electric power. It is, therefore, important to have a big interest in a hybrid generation system that makes use of the rich source of wind by connecting wind turbines with the established power system in parallel(Song et al., 2003; Slootweg \& Kling, 2003).

A wind turbine has output characteristics in which the output power follows the cube of the blowing wind speed which is an uncontrollable element apart from other generating sources. This means that the output power of a wind turbine cannot be controlled. When it connects with a weak grid system of a diesel generation system, it can cause potential unstable elements that can bring about various power problems. Thus, it is necessary that the possible problems according to wind speed be predicted and analyzed when a wind turbine is connected with the existing generating source(Jeong et al., 2007). The purpose of this study is, therefore, to examine voltage variation among several power quality problems that appear when wind speed increases; that is, the output increases at the connecting point between wind turbine and diesel generating system.

It takes actual islands as a model to inquire into what elements other than output variation of wind turbine affect voltage variation at the PCC (Point of Common Coupling) at which a wind turbine is connected with the existing power system. This then tries to predict the amount of voltage variation in advance based on rated capacity of wind turbine to be established and short circuit capacity at the connecting point. It is, ultimately, expected that this study would contribute to predicting power quality including voltage variation when the small-sized wind power generating system is installed and operated in domestic islands, cutting down the cost of power production in islands by ensuring security and reliability of carrying out projects, and improving the penetration ratio of new renewable energy source. 


\section{System modeling}

In order to carry out this study, a domestic island was chosen to operate on by building a small-sized electric power network, which was sampled. The electric power network and the connected wind turbine were modeled briefly and the amount of voltage variation through the simulation based on PSCAD/EMTDC was verified. The Sapsido system as a simplified model formed with power impedance and load impedance was suggested and the amount of voltage variation calculated. Also, the elements which affect voltage variation at the Point of Common Coupling (PCC) of wind turbine through actual measurement by comparing three results was confirmed(KEPC, 2005; IEEE 1547, 2003; E-On Netz GMBH, 2006).

\subsection{Equivalent iron loss resistance}

This paper made a model by simplifying the Sapsido system located in Boryeong, Chungcheongnamdo to develop the model that a small-sized wind turbine is connected to a system. Sapsido is a small island with an area of $3.78 \mathrm{~km}^{2}$ located in Boryeong, Chungcheongnamdo. The formation of the overall power supply line in Sapsido, which is an isolated system, is shown in Fig. 1 by obtaining data at the spot. The total 4 diesel generators are being operated and supply power in Sapsido has a $900[\mathrm{~kW}]$ facility capacity. Electric power produced at a power plant is supplied to every kind of load through transformers and lines within the island, and a $10[\mathrm{~kW}]$ wind turbine is installed and connected to a low voltage line on the seashore.

In order to make the Sapsido system as a model, the power supply line at Fig. 1 is simplified as that of Fig. 2 in which a diesel generator, transformer and loads are indicated in the diagram of Fig. 1. Also, Fig. 2 is formed by regarding the point that a $10[\mathrm{~kW}]$ wind turbine is connected to a power supply system as PCC (Point of Common Coupling). Load is divided into Load 1, which is the total one at the front of the wind turbine, and Load 2, which is one at the village on the seashore for the simple modeling.

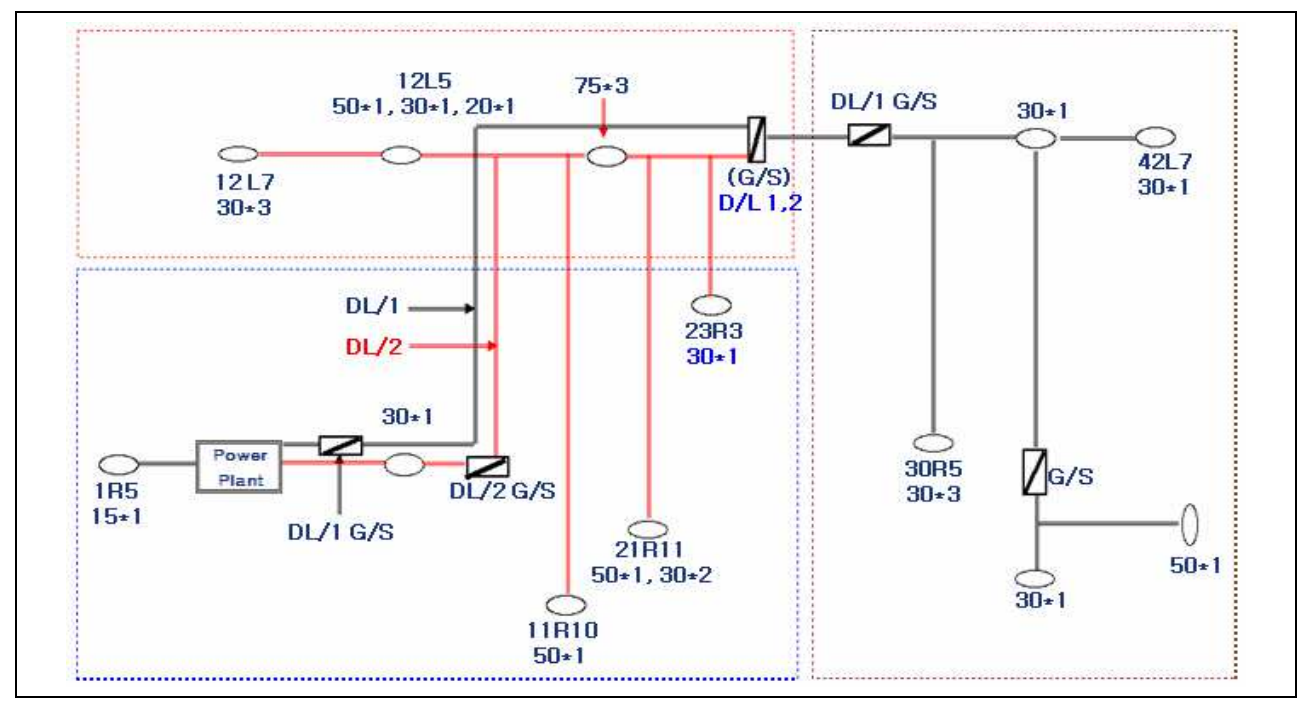

Fig. 1. Power system line diagram in Sapsido 


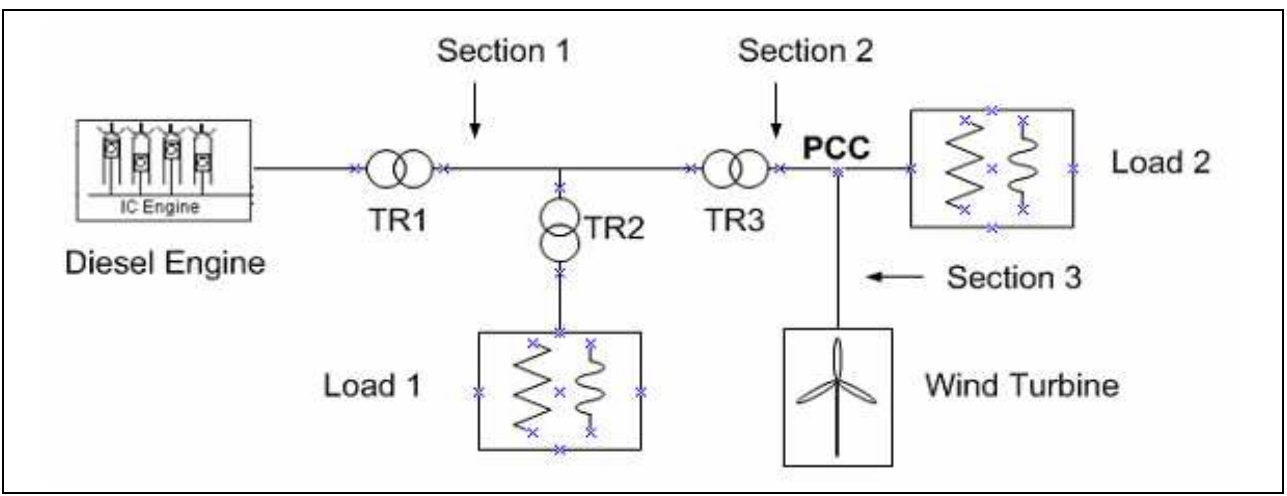

Fig. 2. Outline of power supply system in Sapsido

A more detailed explanation of the components is shown in Table 1. All contents of Table 1, except for the generator, are applied in modeling and only one $300[\mathrm{kVA}]$ generator is modeled for convenience of modeling.

Impedance of the line attains its scale value at the point indicated as the section in Fig. 2, just as indicated in Table 2 according to kinds and length of cable. It applies an almost similar value even though there is little difference according to each manufacturing company.

\begin{tabular}{|c|c|c|}
\hline Classification & Explanation & Reference \\
\hline Diesel Generator & $\begin{array}{c}\text { Sapsido independent generator } \\
\text { (4 generators total) }\end{array}$ & $\begin{array}{c}150[\mathrm{kVA}] \text { 2set } \\
300[\mathrm{kVA}] \text { 2set }\end{array}$ \\
\hline TR1 & $380 / 6600[\mathrm{~V}]$ booster transformer & $750[\mathrm{kVA}]$ \\
\hline TR2 & $6600 / 380[\mathrm{~V}]$ drop transformer & $120[\mathrm{kVA}]$ \\
\hline TR3 & $6600 / 380[\mathrm{~V}]$ drop transformer & $15[\mathrm{kVA}]$ \\
\hline Load 1 & $\begin{array}{c}\text { Load of whole island except for 2 } \\
\text { houses in the village on the seashore }\end{array}$ & $\begin{array}{c}\text { Maximum load } 120[\mathrm{~kW}] \\
50[\mathrm{kVAR}]\end{array}$ \\
\hline Load 2 & $\begin{array}{c}\text { Single phase load of 2houses } \\
\text { in the village on the seashore }\end{array}$ & $\begin{array}{c}10[\mathrm{~kW}], 92 \sim 93 \% \text { power } \\
\text { factor }\end{array}$ \\
\hline Wind Turbine & BERGEY, BWT-10240 & Single phase 10[kW] \\
\hline
\end{tabular}

Table 1. Power system parameter in Sapsido

\begin{tabular}{|c|c|c|c|}
\hline Section & Sort & Distance $[\mathrm{m}]$ & Scale line Resistance $[\Omega]$ \\
\hline Section 1 & ACSR-AW/OC 8[mm²] & 93 & 0.0484 \\
\hline Section 2 & OW $22\left[\mathrm{~mm}^{2}\right]$ & 93,139 & $\begin{array}{c}0.0849 \\
0.1273\end{array}$ \\
\hline Section 3 & OW $22\left[\mathrm{~mm}^{2}\right]$ & 89 & 0.0849 \\
\hline
\end{tabular}

Table 2. Data of power supply line in Sapsido 


\subsection{PSCAD modeling of Sapsido power system full model}

This paper developed a simulation model of the power supply system in Sapsido by using PSCAD/EMTDC, and emulated output variation of wind turbine with the model(Rajendiran et al.). A simulation model was made up based on the power supply system in Sapsido in Fig. 2, and the exciter and the governor of diesel generator at a power plant were assumed as ideal ones(Bialasiewics et al., 1998).

A grid connected inverter that adopts the up-to-date Digital Signal Processor (DSP) takes the role of connecting the output of variable DC voltage of decentralized power from not only a wind turbine but also a solar and fuel cell with the power system containing constant voltage and frequency. If it is presumed that the loss of an inverter operated by PWM switching method is very small and that the AC power that is almost the same as the input DC power will be generated, which will finally reveal output current variation.

Fig. 3 shows the inner structure of the installed grid connected wind turbine system and the simplified equivalent modeling of the grid connected inverter(Kim \& Song, 2005). Fig. 4 is designed to generate a current with the same phase as the system voltage by adopting a Phase Locked Loop (PLL) on a grid connected inverter because the power production synchronized with the phase of a power system voltage should be essential in case of grid connection of an AC generating power.

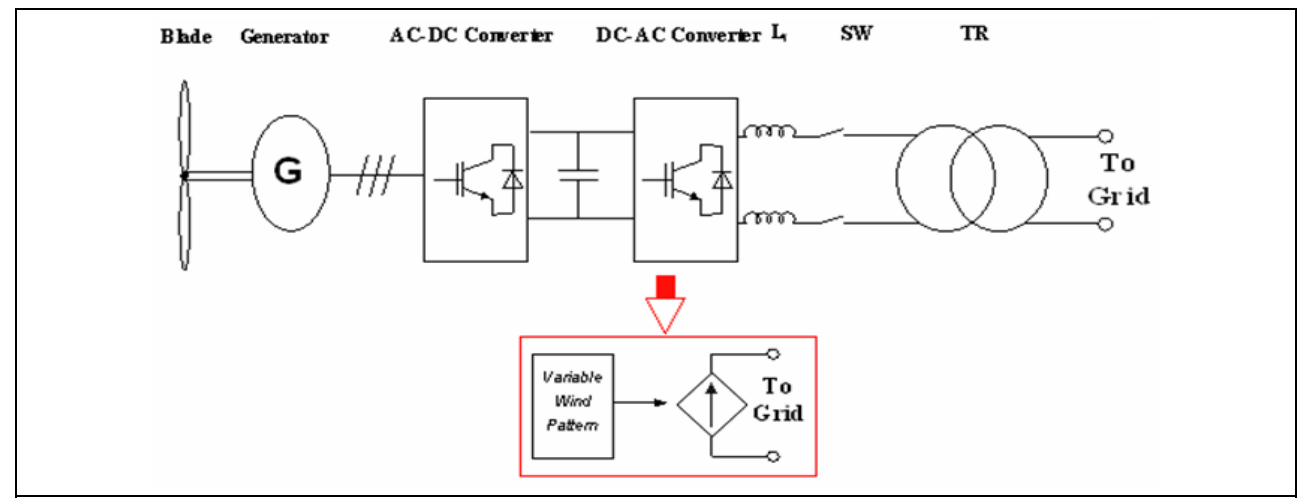

Fig. 3. Wind turbine \& Grid connected inverter model

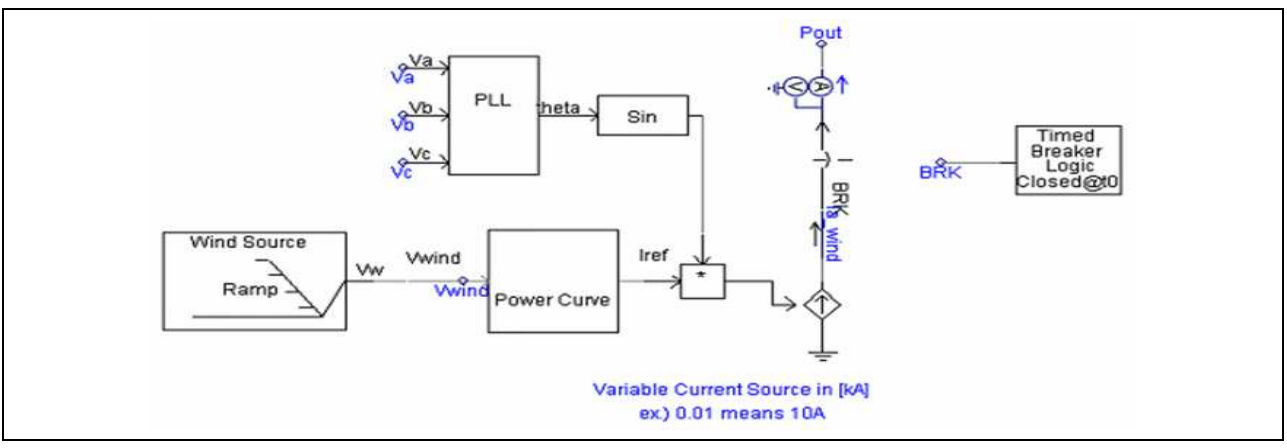

Fig. 4. Simulation model of wind turbine 
Fig. 5 is a graph which indicates the variation of power output according to Excel-S wind speed. This paper takes the characteristics of Excel-S which is a $10[\mathrm{~kW}]$ model of two models(www.windturbinewarehouse.com).

The simulation model in Fig. 4 takes on a kind of sinusoidal wave current without the modeling of separate equipment for the simplified modeling based on the model of an Excel-S wind turbine. Wind speed input is fixed to generate $10[\mathrm{~kW}]$ at $16[\mathrm{~m} / \mathrm{s}]$ according to the characteristics in Fig. 5.

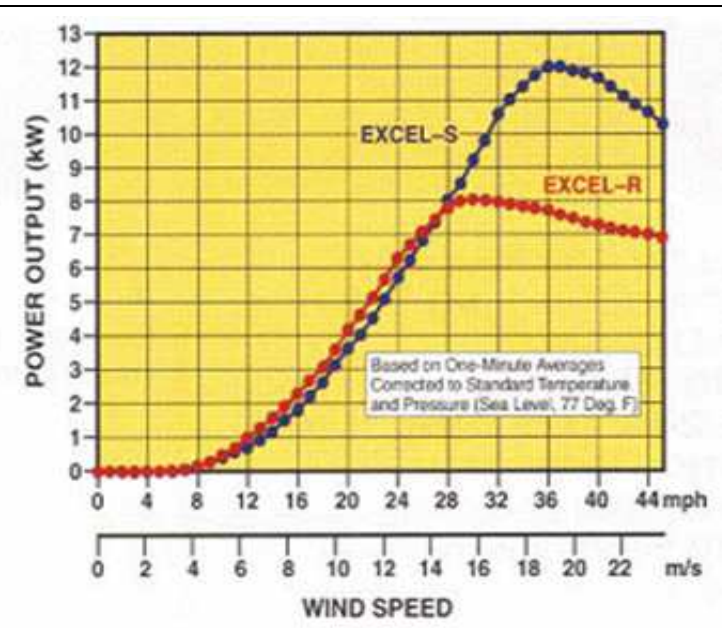

(a)

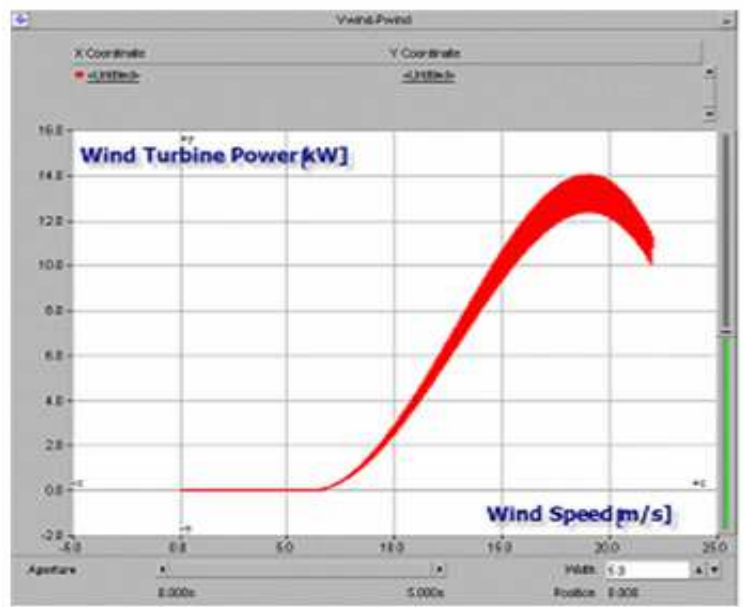

(b)

Fig. 5. The compare of characteristic curves

(a) The characteristic curve of wind turbine output

(b) The output characteristics of simulation model of wind turbine 
Fig. 5 (b) shows the output characteristics of the simulation model of the developed wind turbine per wind speed. We can see that it accords with the characteristics in Fig. 5 (a).

Fig. 6 shows the overall simulation model in Sapsido. All parameters follow to the actual ones, and a grid connected inverter is operating as the control system of output current in proportion to the variation of output power(Sim et al., 2007).

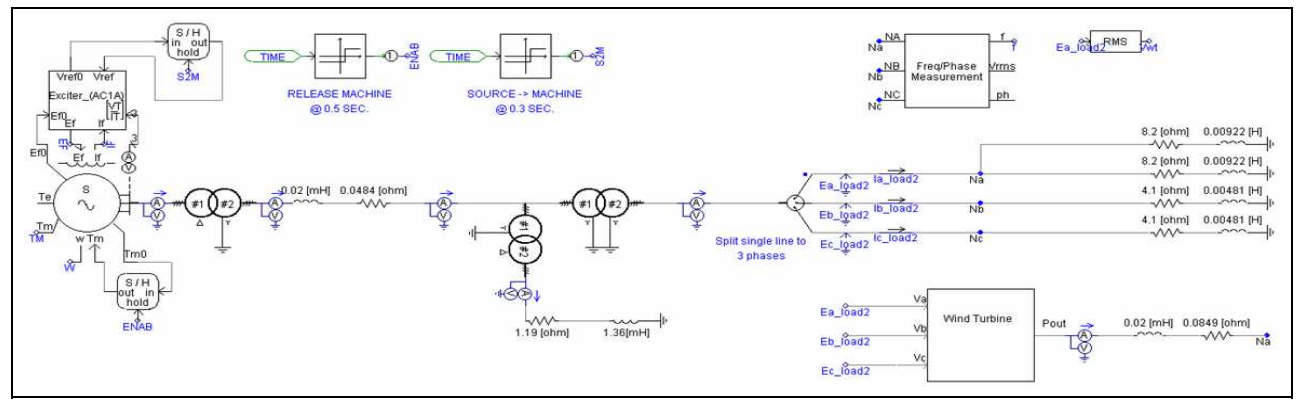

Fig. 6. The simulation formation of power supply system in Sapsido

In simulation, it is observed by emulating the variation of wind speed to investigate the influences in case of grid connected operation from the perspective of voltage variation. If the output of a wind turbine increases under the condition of a constant load, the power plant can reduce as much as the output amount. A graph in Fig. 7 can be gained when the RMS voltage at PCC is observed through the simulation model according to the output of the wind turbine. The output of the wind turbine shows the voltage variation from $6[\mathrm{~kW}]$ to about 6-7[V].

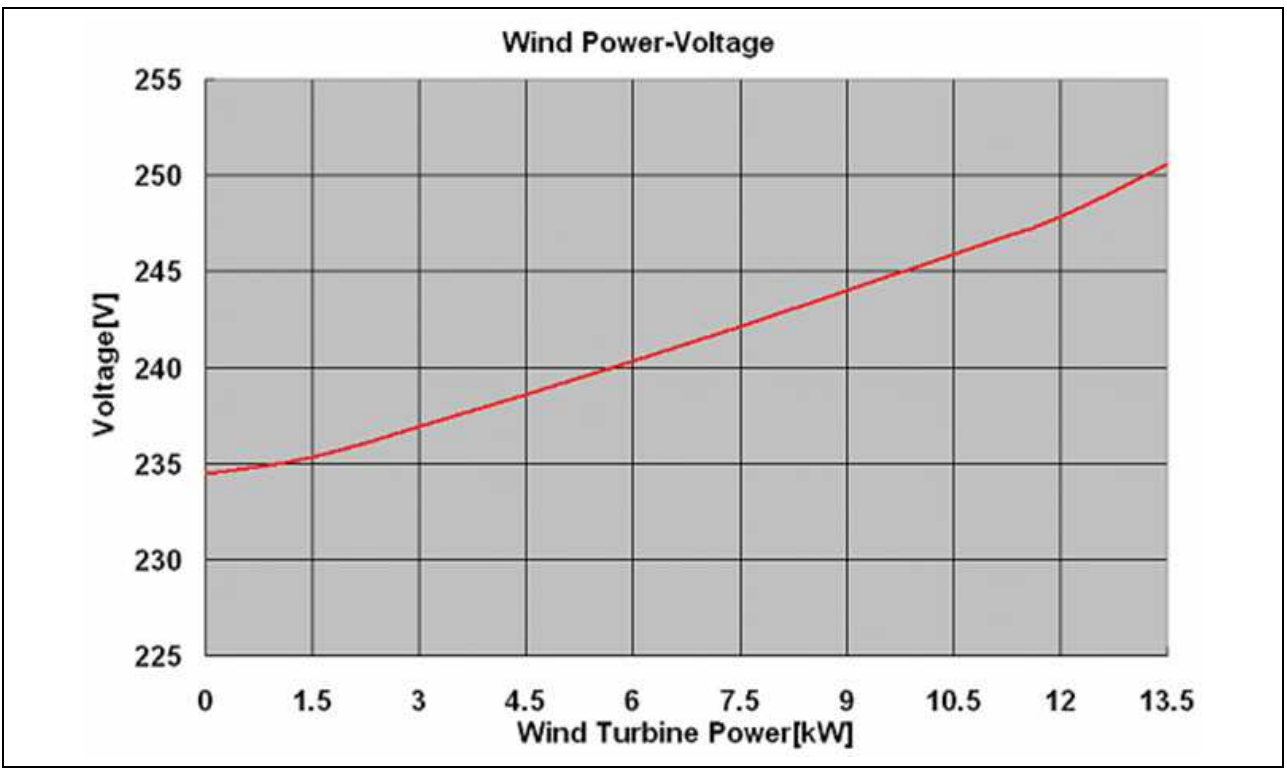

Fig. 7. The simulation of PCC voltage variation in case of wind speed change 


\subsection{Simplified prediction model for voltage variation study}

The overall impedance of the power system in Sapsido can be indicated as shown in Fig. 8 to analyze not the simulation as the above executed, but the actual voltage variation.

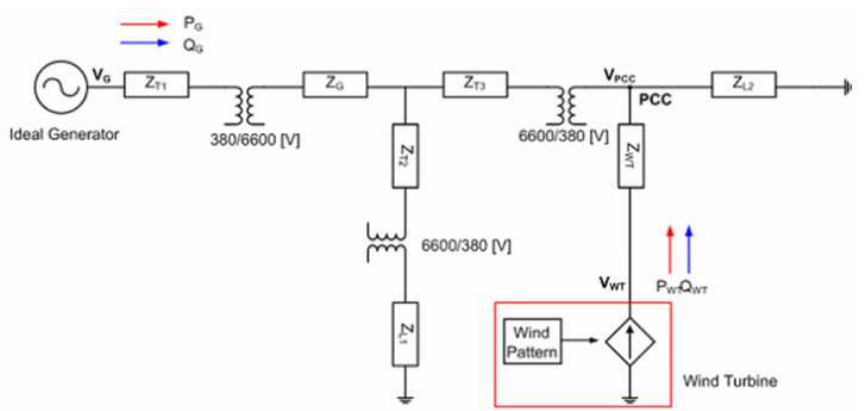

Fig. 8. The overall impedance of Sapsido system

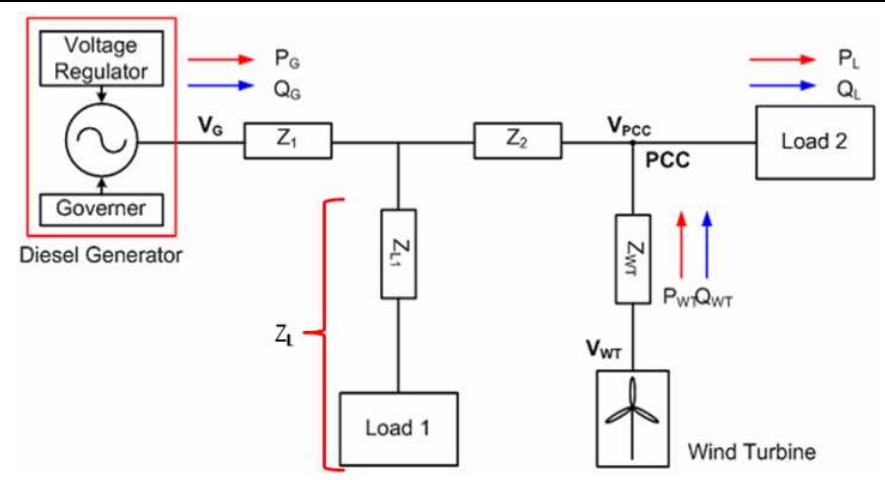

Fig. 9. The simplified impedance formation of power system in Sapsido

System impedance in Sapsido as shown in Fig. 8 can be more simplified as shown in Fig. 9, and indicated as shown in Fig. 10 if the Load1 impedance is much higher than the line impedances $Z_{1}$ and $Z_{2}$.

The total equivalent line impedance $Z_{G}$ can be expressed as (1).

$$
Z_{G} \approx Z_{1}+Z_{2}
$$

In Fig. 10, the equivalent load impedance $Z_{\mathrm{LL}}$ includes the line impedance $Z_{\mathrm{L}}$ to the load and the load impedance $Z_{\text {Load }}$ as shown in (2). When load current $I_{L}$ is fixed, output current $I_{G}$ is changed as shown in (3) if output current IWT of the wind turbine is changed. It can be shown as (4) and (5) if it is indicated in terms of power.

$$
\begin{gathered}
Z_{L}+Z_{\text {Load }}=Z_{L L} \\
I_{G}+I_{W T}=I_{L}
\end{gathered}
$$




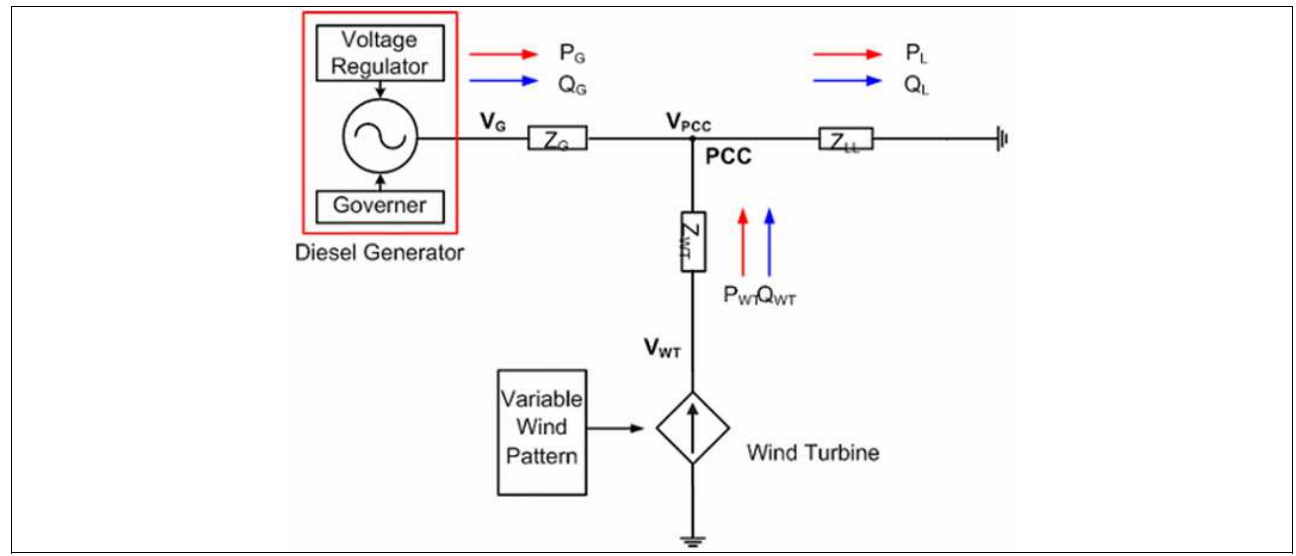

Fig. 10. The simplified model connected with wind turbine

$$
\begin{gathered}
P_{G}+P_{W T}=P_{L} \\
Q_{G}+Q_{W T}=Q_{L}
\end{gathered}
$$

The voltage $\mathrm{V}_{\mathrm{PCC}}$ at the grid connected point can be shown as (6). PCC voltage is composed of the first term by the existing internal voltage source $V_{G}$ and the second one by current source IWT of the wind turbine from the principle of superposition shown in Fig. 11.

$$
V_{P C C}=\left(\frac{Z_{L L}}{Z_{L L}+Z_{G}}\right)\left(V_{G}+Z_{G} I_{W T}\right)
$$

Fig. 11(a) shows the case that wind turbine is not working $\left(\mathrm{I}_{W T}=0\right)$, and PCC voltage is determined as (7) by impedance distribution between power side and load one. The PCC voltage without wind power generation $\left(\mathrm{I}_{W T}=0\right)$ can be considered as nominal voltage $V_{P C C 0}$ in (7). The nominal voltage is determined by source voltage $V_{G}$ and the impedance distribution. From (6) and (7) the PCC voltage variation, $\triangle V_{P C C}$ due to the wind power is proportional to $I_{W T}$ and the equivalent effective impedance $Z_{\text {effect }}$ as (8).

These results can also be explained using the principle of superposition in Fig. 11. Z $Z_{\text {effect }}$ corresponds to parallel impedance of $Z_{\mathrm{G}}$ and $\mathrm{Z}_{\mathrm{LL}}$ as shown in (9). There is one thing to watch out here that line impedance $Z_{W T}$ connected to current source $I_{W T}$ in series does not affect PCC voltage variation; instead, it affects port voltage $V_{W T}$ of the wind turbine according to the change of current $\mathrm{I}_{\mathrm{WT}}$ as shown in (10).

$$
\begin{gathered}
V_{P C C 0}=\left(\frac{Z_{L L}}{Z_{L L}+Z_{G}}\right) V_{G} \\
\Delta V_{p C C}=Z_{\text {effect }} \cdot I_{W T} \\
Z_{\text {effect }}=\frac{Z_{L L} \cdot Z_{G}}{Z_{L L}+Z_{G}}
\end{gathered}
$$




$$
V_{W T}=V_{p C C}+Z_{W T} \cdot I_{W T}
$$

Here,

$\mathrm{V}_{\mathrm{G}}$ : output voltage of internal generator

$\mathrm{I}_{\mathrm{WT}}$ : output current of wind turbine

$Z_{\text {Load }}$ : equivalent load impedance

$\mathrm{Z}_{\mathrm{G}}$ : equivalent circuit impedance between internal generator and PCC

$\mathrm{Z}_{\mathrm{L}}$ : equivalent line impedance between $\mathrm{PCC}$ and load

$\mathrm{Z}_{\mathrm{WT}}$ : line impedance between PCC and wind turbine

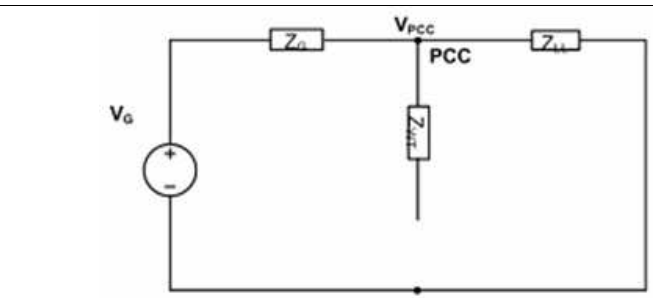

(a)

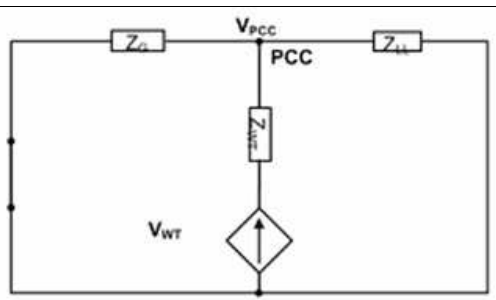

(b)

a) The case that wind turbine is not working $\left(\mathrm{I}_{\mathrm{WT}}=0\right)$

b) The analysis of voltage variation port by I $_{W T}$ in case of operating wind turbine

Fig. 11 The analysis of equivalent circuit of the connected model with wind turbine

In order to verify the analysis, the analysis is done by converting impedance in Fig. 8 into the actual impedance parameter such as in Table 3.

\begin{tabular}{|c|c|c|}
\hline Classification & Explanation & Reference \\
\hline $\begin{array}{c}\text { Ideal } \\
\text { Generator }\end{array}$ & $\begin{array}{c}\text { Sapsido power plant } \\
\text { (3 phase) }\end{array}$ & $380[\mathrm{~V}]$ \\
\hline $\mathrm{Z}_{\mathrm{T} 1}$ & $\begin{array}{c}750[\mathrm{kVA}] \text { transformer impedance } \\
\text { (380[V] scale value) }\end{array}$ & $0.013 \angle 71.57$ \\
\hline $\mathrm{Z}_{\mathrm{T} 2}$ & $\begin{array}{c}120[\mathrm{kVA}] \text { transformer impedance } \\
\text { (380[V] scale value) }\end{array}$ & $0.076 \angle 71.57$ \\
\hline $\mathrm{Z}_{\mathrm{T} 3}$ & $\begin{array}{c}15[\mathrm{kVA}] \text { transformer impedance } \\
\text { (380[V] scale value) }\end{array}$ & $0.611 \angle 71.57$ \\
\hline $\mathrm{Z}_{\mathrm{G}}$ & $\begin{array}{c}\text { Line impedance of high voltage side } \\
\text { (380[V] scale value) }\end{array}$ & $0.0002 \angle 7.13$ \\
\hline $\mathrm{Z}_{\mathrm{L} 1}$ & $\begin{array}{c}\text { Load impedance of whole island } \\
\text { except for }\end{array}$ & $1.35 \angle 25.73$ \\
\hline $\mathrm{Z}_{\mathrm{L} 2}$ & $\begin{array}{c}\text { Load impedance of } 2 \text { houses in the } \\
\text { village on the seashore }\end{array}$ & $4.45 \angle 23$ \\
\hline $\mathrm{Z}_{\mathrm{WT}}$ & Line impedance of wind turbine side & $0.085 \angle 5.05$ \\
\hline
\end{tabular}

Table 3. The actual impedance parameter

The simplified impedance shown in Fig. 10 is indicated in Table 4 below. 


\begin{tabular}{|c|c|c|}
\hline Classification & Explanation & Value \\
\hline $\begin{array}{c}\text { Ideal } \\
\text { Generator }\end{array}$ & Sapsido power plant (3 phase) & $380[\mathrm{~V}]$ \\
\hline $\mathrm{Z}_{\mathrm{G}}$ & Scale line impedance & $0.625 \angle 72.37$ \\
\hline $\mathrm{Z}_{\mathrm{LL}}$ & Scale load impedance & $4.19 \angle 22.24$ \\
\hline $\mathrm{Z}_{\mathrm{WT}}$ & Line impedance of wind turbine side & $0.085 \angle 5.05$ \\
\hline
\end{tabular}

Table 4. Scale impedance parameter

$$
\begin{gathered}
\therefore Z_{\text {effect }}=\frac{Z_{L L} \cdot Z_{G}}{Z_{L L}+Z_{G}}=0.57 \angle 66.4^{\circ} \\
\therefore \Delta V_{p C C}=0.57 \angle 66.4^{\circ} \times I_{W T}
\end{gathered}
$$

The final equation on voltage variation occurring at the actual PCC with data in Table 4 is shown in (11) and (12).

\subsection{The actual measurement}

Data is measured by installing a power measuring instrument at the PCC step within the actual system in Sapsido to enhance reliability in this study. Fig. 12 shows the location where measurement is carried out. Valid/invalid power graph of the wind turbine according to time based on this measured data is shown in Fig. 13.

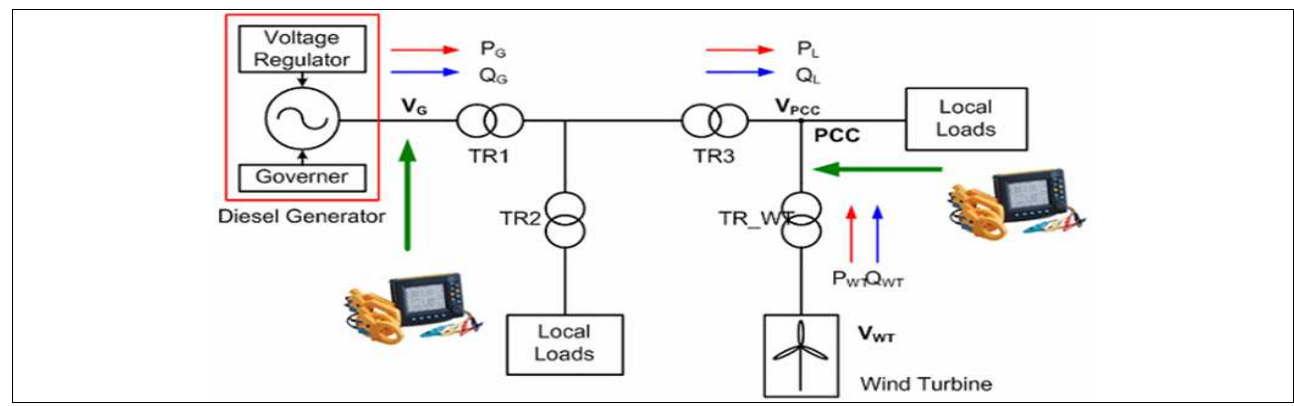

Fig. 12. Measuring location of power in Sapsido

Fig. 14 shows voltage variation amount for the output. The measured dots show the tendency of increase proportional to the power output and are represented as a solid line. Dots inside the circle, near zero output power, show the voltage variation in normal operating conditions at the PCC even without wind power generation. An approximate 7[V] voltage variation is shown in case of producing about $5.5[\mathrm{~kW}]$.

Table 5 shows the comparative results of the voltage variation using two simulation models and one experimental measurement.

At first, the voltage variation of $6.4 \mathrm{~V}$ results from the PSCAD simulation model which has full modeling of the wind turbine and complex line impedance parameters. The second result of $6.5 \mathrm{~V}$ comes from the proposed simplified prediction model of PCC voltage using (8). The last result of $6.9 \mathrm{~V}$ PCC voltage deviation is a measured value as shown in Fig. 14 during the field test. 
From this comparison the result of the proposed prediction model highly matches the simulation and measurement results.

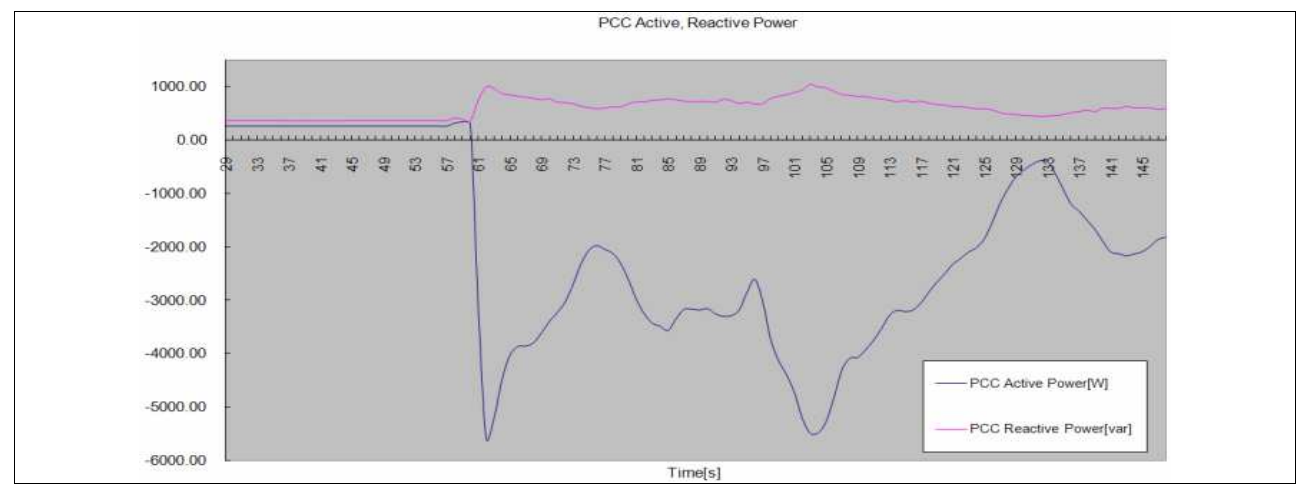

Fig. 13. PCC valid invalid power in case of wind speed change

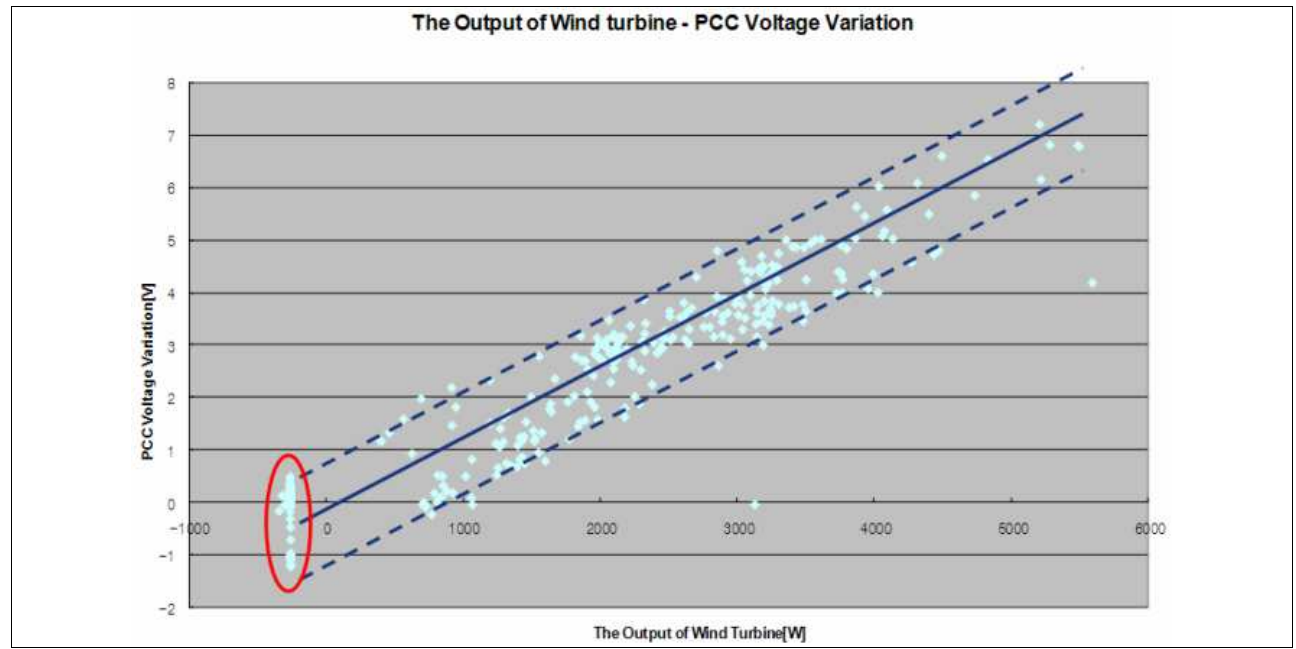

Fig. 14. Measured value of PCC voltage variation amount for the output of wind turbine

\begin{tabular}{|c|c|}
\hline Classification & $\begin{array}{c}\text { Amount of voltage variation in case } \\
\text { of 5.5[kW] generation (V) }\end{array}$ \\
\hline PSCAD Model & 6.4 \\
\hline $\begin{array}{c}\text { Simplified } \\
\text { prediction model }\end{array}$ & 6.5 \\
\hline $\begin{array}{c}\text { Results of actual } \\
\text { measurement }\end{array}$ & 6.9 \\
\hline
\end{tabular}

Table 5. The comparative table of PCC voltage variation amount in case of active power fluctuation of wind turbine 


\section{Conclusion}

This study analyzed voltage variation according to the active power fluctuation of a wind turbine connected with the existing generating facilities in parallel in a small-sized isolated system, e.g. an island. The prediction of the voltage variation amount at the connected point is possible under the consideration of the change of installation location of a wind turbine and load fluctuation in the future. The variations of voltage drop happen according to the fluctuation of generated wind amount, and voltage change (rising) in receptive value inevitably. The simulation model was developed by using PSCAD/EMTDC to analyze voltage variation of the simplified model in the small-sized isolated system; and suggested the method to analytically obtain voltage variation amount through the analysis of a lot more generalized equivalent circuit. It was confirmed that the suggested method, simulation and the results of actual measurement matched in the error range of about less than $7 \%$. It is considered that the study on the additional control method of a wind turbine to make the penetration ratio of wind plant increase in comparison to load capacity is necessary along with the development of a much more precise simulation model by taking account of the uniqueness of the excessive condition of generators in the future.

\section{References}

Bialasiewicz, J; Muljadi, E. \& Drouilhet, S. \& Nix, G. (1998) Modular Simulation of a Hybrid Power System with Diesel and Wind Turbine Generation, Windpower 198 Bakersfield, CA

E-ON Netz Gmbh, (2006) Grid Code-High and Extra High Voltage

IEEE 1547 (2003) IEEE Standard for Interconnecting Distributed Resources with Electric Power Systems

Jeong, W.; Yoon, K. \& Kim, S. \& Lee, H. (2007) The analysis of voltage variation according to grid connection at wind plant in Yangyang, International Spring Academy Conference of Korea Wind Energy, papers, 35-40

Kim, J. \& Song, H. (2005) The development of PSCAD/EMTDC simulation model of variable speed wind plant system by permanent magnet synchronous generator, Society of Power E Electronics, papers, 610-617

Korea Electric Power Corporation (2005) Technology standard connected with the distributed power supply system

Rajendiran, K.; Keerthipala, W. \& Nayar, C. PSCAD/EMTDC Based Simulation of a WindDiesel Conversion Scheme

Sim, M.; Palle, B. \& Chakraborty, S. \& Uriarte, C. (2007) Electrical Model Development and Validation for Distributed Resources, Subcontract Report, NREL

Slootweg, J. \& Kling, W. (2003) Is the Answer Blowing in the Wind?, IEEE Power \& Energy Magazine, No., 6, 26-33

Song, S.; Kim, I. \& Han, B. (2003) Electric characteristics of wind turbine and interaction in case of grid connection, Power \& Electronics Magazine, Ed., Vol., 8, No., 6, 21-27

www.windturbinewarehouse.com/pdgs/bergey/BergeyExcel-S 10kW Turbine Specs.03.pdf 


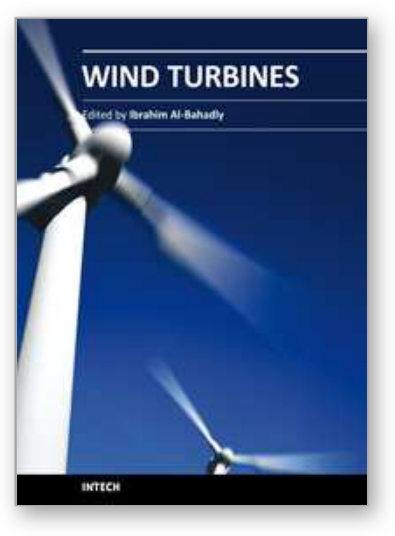

\author{
Wind Turbines \\ Edited by Dr. Ibrahim Al-Bahadly
}

ISBN 978-953-307-221-0

Hard cover, 652 pages

Publisher InTech

Published online 04, April, 2011

Published in print edition April, 2011

The area of wind energy is a rapidly evolving field and an intensive research and development has taken place in the last few years. Therefore, this book aims to provide an up-to-date comprehensive overview of the current status in the field to the research community. The research works presented in this book are divided into three main groups. The first group deals with the different types and design of the wind mills aiming for efficient, reliable and cost effective solutions. The second group deals with works tackling the use of different types of generators for wind energy. The third group is focusing on improvement in the area of control. Each chapter of the book offers detailed information on the related area of its research with the main objectives of the works carried out as well as providing a comprehensive list of references which should provide a rich platform of research to the field.

\title{
How to reference
}

In order to correctly reference this scholarly work, feel free to copy and paste the following:

Sang-Jin Kim and Se-Jin Seong (2011). A Simple Prediction Model for PCC Voltage Variation Due to Active Power Fluctuation for a Grid Connected Wind Turbine, Wind Turbines, Dr. Ibrahim Al-Bahadly (Ed.), ISBN: 978-953-307-221-0, InTech, Available from: http://www.intechopen.com/books/wind-turbines/a-simpleprediction-model-for-pcc-voltage-variation-due-to-active-power-fluctuation-for-a-grid-conne

\section{INTECH}

open science | open minds

\author{
InTech Europe \\ University Campus STeP Ri \\ Slavka Krautzeka 83/A \\ 51000 Rijeka, Croatia \\ Phone: +385 (51) 770447 \\ Fax: +385 (51) 686166 \\ www.intechopen.com
}

\author{
InTech China \\ Unit 405, Office Block, Hotel Equatorial Shanghai \\ No.65, Yan An Road (West), Shanghai, 200040, China \\ 中国上海市延安西路65号上海国际贵都大饭店办公楼405单元 \\ Phone: +86-21-62489820 \\ Fax: $+86-21-62489821$
}


(C) 2011 The Author(s). Licensee IntechOpen. This chapter is distributed under the terms of the Creative Commons Attribution-NonCommercialShareAlike-3.0 License, which permits use, distribution and reproduction for non-commercial purposes, provided the original is properly cited and derivative works building on this content are distributed under the same license. 